\title{
Otokritik Bali lewat Ironi Industri Pariwisata
}

\author{
I Nyoman Darma Putra
}

Email: idarmaputra@yahoo.com

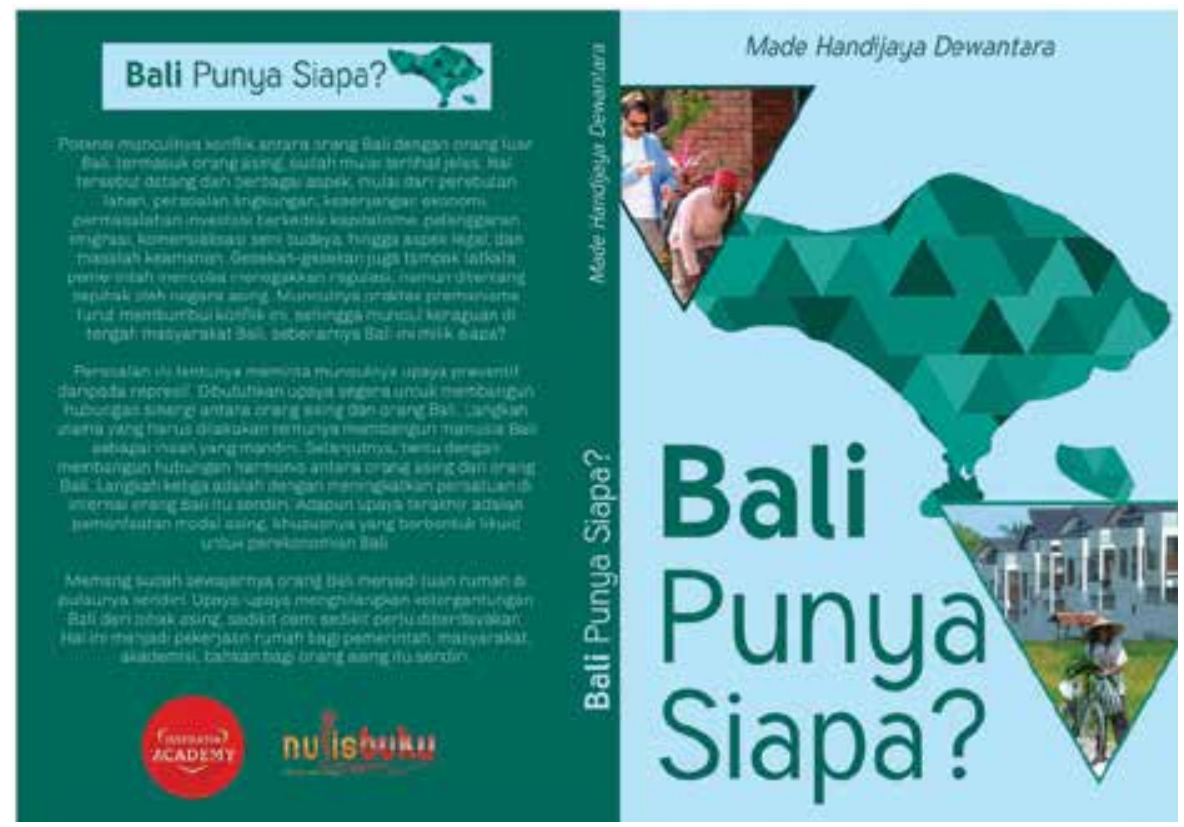

$\begin{array}{ll}\text { Judul Buku } & \text { : Bali Punya Siapa? } \\ \text { Pengarang } & \text { : Made Handijaya Dewantara } \\ \text { Penerbit } & \text { : Inspirator Academy } \\ \text { Tahun terbit } & : 2015 \\ \text { Tebal } & : 183 \text { halaman } \\ \text { Harga buku } & \text { : Rp 65.000,- }\end{array}$

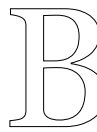

uku Bali Punya Siapa? merupakan wujud keprihatinan penulisnya, Made Handijaya Dewantara, SST. Par., M. Par., M.E., atas berbagai fenomena ironis dalam kehidupan masyarakat Bali yang serta-merta dikaitkan dengan dampak negatif dari industri pariwisata Bali. Buku ini 
terdiri dari empat bab yaitu "Potensi Konflik Orang Asing dan Orang Bali", "Mulai Tergradasinya Nilai Bali", "Posisi Tawar Si Bali", dan "Strategi Kolaborasi Orang Bali-Orang Asing”. Seperti tercermin dari judul-judul babnya, keseluruhan isi buku memang merupakan sebuah otokritik Bali oleh sarjana Bali sendiri.

Buku ini merupakan hasil pengamatan dan kajian komparasi Made Handidjaya selama dia berpetualang ke Asia dan Eropa, serta wawancara yang dia lakukan pada sesama orang Bali. Alumnus Prodi Magister Kajian Pariwisata Universitas Udayana yang gemar berdiskusi dan berolahraga ini berharap agar rakyat Bali cepat sadar dan mengubah pola pikirnya, dari jangka pendek ke jangka panjang. Jika tidak, pelan-pelan kemajuan pariwisata Bali akan membuat orang Bali akan kian terasing di daerahnya sendiri.

Buku ini mengambil tema yang multidimensional yaitu menggabungkan tema ekonomi dan memasukkan unsur politik, sosial, budaya, dan kemasyarakat menjadi suatu kemasan yang menarik. Topik yang diambil dalam buku ini cukup spesifik yaitu mengenai ironi yang terjadi di Pulau Bali, yang mana menjadi pulau tempat kelahiran penulis. Banyak hal yang menjadi wacana publik atau wacana media massa dibahas dalam buku ini sehingga terasa aktual.

Setidaknya ada tiga kelebihan buku ini. Pertama, buku ini mengulas topik yang aktual sehingga sangat berguna bacaan bagi masyarakat umum. Di samping secara substansi, buku ini juga memiliki keunggulan seperti katakatanya yang mudah dipahami oleh berbagai khalayak. Kedua, banyaknya contoh yang dimasukkan ke dalam buku juga mempermudah pembaca untuk ikut menyelami jalan pikiran penulis. Ketiga, adanya tambahan foto dan gambar tentunya juga memandu secara langsung pembaca kepada maksud dan tujuan penulis pada setiap babnya.

Mengingat pengalaman penulisnya bepergian ke berbagai negara termasuk saat kuliah setahun menempuh program master bidang pariwisata di Perancis, Made Handijaya memberikan perspektif global dalam membahas isu-isu lokal di Bali dalam buku ini. Dia misalnya mengatakan bahwa sebagian besar khalayak internasional berpikir bahwa Bali merupakan sebuah negara sendiri dan Indonesia merupakan bagian dari negara Bali itu sendiri. Beberapa orang berpendapat bahwa Bali merupakan pulau wajib yang harus dikunjungi sebelum mereka meninggal dunia. Beberapa orang bahkan berpikir lebih ekstrim yaitu dengan menjadikan Bali sebagai surga terakhir sebelum surga yang sebenarnya.

Bagi Made Handidjaya, wajar Bali begitu populer di dunia, mengingat angka-angka fantastis yang ditunjukkan oleh pulau ini dari sektor pariwisatanya. Tahun 2014, Bali mendapat kunjungan 3,5 juta wisatawan mancanegara. Angka ini belum termasuk jumlah wisatawan domestik 
yang mencapai angka 7 juta orang. Tidak hanya angka-angka dari raihan kedatangan turis, lama tinggal wisatawan di Bali pun meningkat dari yang sebelumnya hanya 8 hari, menjadi 9 hari di tahun lalu. Angka ini jelas ampuh dalam mengalahkan data-data statistik destinasi wisata top lainnya seperti Singapura, Kualalumpur, ataupun Phuket di Thailand (hlm 9).

Tak melulu melalui data-data statistik, Bali juga memiliki banyak rekor yang dicetak oleh perusahaan baik hotel maupun destinasi wisata. Sebut saja, Hotel Mulia Bali yang memegang rekor "The Best Spa Resort in The World 2014" versi Majalah Traveler. Kawasan Ubud juga cukup dikenal sebagai destinasi favorit turis-turis di dunia dalam melakukan yoga serta meditasi, setelah film Eat Pray Love mengambil tempat di Bali.

Popularitas Bali semakin meroket dengan kedatangan beberapa artis papan atas dunia, antara lain Paris Hilton, Justin Bieber, Cristiano Ronaldo, hingga David Beckham yang cukup rajin mengunjungi pulau eksotis ini. Terakhir, keberhasilan Bali menjadi tuan rumah ajang internasional, antara lain kompetisi Miss World, konferensi APEC (ekonomi negara-negara Asia Pasifik), hingga KTT ASEAN (negara-negara Asia Tenggara).

Menurut Made Handijaya, Bali selalu memberikan opini-opini positif. Sempat dua kali kena musibah tragedi bom di tahun 2002 dan 2005, serta penurunan popularitas akibat isu keamanan, ekonomi Bali menggeliat lagi di periode 2008-2015. Menggeliatnya ekonomi Bali tidak hanya karena keberhasilannya mejadi host event-event internasional di hotel-hotel di Nusa Dua, namun juga kenyaman bagi para investor untuk berinvestasi. Investasi asing yang masuk tentunya bisa membuka banyak lapangan kerja untuk orang Bali. Membludaknya investasi memberi kesan bahwa orang asing (baik pekerja asing maupun investor) dan orang lokal (orang Bali dan orang Indonesia) mampu hidup rukun, tanpa konflik.

Namun, benarkah demikian? Benarkah anggapan orang-orang Jakarta bahwa orang Bali biasanya diwarisi banyak bidang tanah dari para leluhurnya, dan siap untuk disewakan kepada para orang asing (orang asing)? Benarkah opini bahwa orang asing selama ini menaati dan mematuhi peraturan adat yang diamanatkan setiap desa adat? Sungguhkah orangorang Bali menikmati kedatangan orang asing baik untuk berlibur, bekerja, atau berinvestasi? Apakah mereka dapat menikmati alam warisan leluhur Bali seperti orang asing rasakan? Apakah orang-orang Bali pernah berpikir bahwa seandainya seluruh orang asing akhirnya tertarik datang ke Bali, maka mereka akan hidup dengan berlimpah rejeki?

Kenyataan di lapangan, menurut penulis buku ini, ternyata tidak selalu seindah kata orang. Angka-angka statistik tidak selamanya mendeskripsikan kondisi riil di lapangan. Buku ini mengungkapkan bahwa capaian datadata dan pertumbuhan ekonomi ternyata tidak dirasakan setiap lapisan masyarakat. Bali kemudian mengalami sindrom seperti daerah tujuan wisata 
internasional lainnya, yaitu adanya kesenjangan tinggi antara si kaya dan si miskin, si lokal dan si pendatang. Ada banyak hal yang kemudian berubah semenjak popularitas Bali sebagai pulau dewata meningkat.

Pada bab awal, khususnya dalam subbab “Sawah Bali untuk Siapa?”, buku ini menyoroti hilangnya banyak lahan persawahan. Transformasi lahan ini ikut membuat pertanian dan perkebunan komoditas lokal menjadi tergerus. Ironis sekali, sebagian besar apel yang bereda di pasar buah di Bali berasal dari Australia dan Amerika Serikat. Mengherankan, sebagian besar beras yang dikonsumsi oleh masyarakat Bali berasal dari Thailand dan Vietnam sehingga Bali pun tidak hanya menjadi pasar menggiurkan dari segi industri pariwisatanya, melainkan juga untuk pemenuhan konsumsi pangannya. Lalu bagaimana dengan para petani Bali? Banyak di antara mereka yang terpaksa menjual areal sawah dan ladang mereka karena berbagai alasan.

Makin maraknya pembangunan properti, baik villa maupun hotel, memberikan sinyalemen begitu mudahkah proses investasi yang bisa dilakukan di Bali? Tidakkah terdapat peraturan-peraturan daerah yang mampu menyaring terlalu maraknya pariwisata massal yang dikhawatirkan bisa mengganggu keseimbangan kehidupan antar-masyarakat dan lingkungan di Bali? Adakah peran aktif desa adat (unit terkecil dari kehidupan sosial masyarakat Bali) dalam hal proses pembangunan sebuah properti di Bali? Seorang artis kenamaan ibukota yang juga ikut melakukan kegiatan investasi di Bali menuturkan bahwa berinvestasi di Bali memang tidak sesulit dan tidak serumit dibandingkan berinvestasi di Jakarta atau di Singapura misalnya. Meskipun demikian, menurutnya, bukan berarti kendala-kendala perizinan tidak jarang ditemui di dalam proses kegiatan berinvestasi tersebut.

Bali yang berpenduduk sekitar 3,5 juta, dibanjiri sekitar 10 juta turis baik asing maupun domestik setiap tahunnya. Namun, ketiadaan sistem transportasi yang handal menyebabkan hampir 99\% penduduk Bali menggunakan kendaraan pribadi dalam mobilisasi dari satu tempat ke tempat yang lain. Kegagalan Bali dalam mengelola sistem transportasi publik sudah cukup sering dicermati dari mulai masyarakat lokal hingga wakil presiden. Bali yang dipandang sebagai wajah Indonesia di mancanegara semestinya dapat memberikan contoh khususnya dalam kenyamanan di lalu lintas.

Dalam buku ini, Made Handi juga menyoroti motivasi orang asing untuk pergi ke Bali saat ini sudah mulai beragam. Sebagian besar orang asing memang datang ke Bali untuk berlibur atau sebagai turis, namun tidak sedikit orang asing yang akhirnya memutuskan untuk menetap di Bali karena terpesona dengan keindahannya. Di antara orang asing-orang asing yang menetap itu, beberapa orang asing melakukan aktivitas berbisnis, beberapa orang pensiun, beberapa orang asing menghabiskan waktu liburan 
yang lama, bekerja jarak jauh atau online, dan tidak sedikit pula yang bekerja dengan perusahaan internasional yang ada di Bali.

\section{Sorga bagi Pencari Kerja}

Sebuah group virtual di jejaring sosial bernama Bali expat jobs adalah ajang bagi para ekspatriat di Bali yang ingin mencari pekerjaan di perusahaan-perusahaan baik nasional maupun internasional di Bali. Group tersebut memberikan gambaran betapa Bali sekarang semakin eksotis tidak hanya bagi pelancong, melainkan juga bagi pencari kerja (hlm 51). Pada subbab “Tanpa KITAS Kadang Tidak Masalah" penulis buku ini mencoba menyampaikan ironi mudahnya orang asing mencari pekerjaan, tanpa disadari sedikit pun oleh orang Bali itu sendiri. Pemerintah pun terasa bergeming dan bahkan tebang pilih dengan merazia banyak pekerja Bali ilegal sementara membiarkan pekerja asing ilegal berkeliaran.

Sejarah dan berita mencatat bahwa berbagai macam konflik bisa terselesaikan dengan adanya komunikasi. Salah satu pilar penting dalam berkomunikasi adalah berbahasa, atau menggunakan bahasa. Mengikuti logika sebelumnya, maka akan sangat elok kalau orang asing bisa menggunakan bahasa Indonesia untuk memahami dan mengerti serta mulai berkomunikasi dengan orang Bali. Sayangnya, karena orang asing pada umumnya mengenal Bali sebagai destinasi pariwisata internasional sehingga mereka menganggap semua orang Bali bisa berkomunikasi dengan bahasa Inggris. Anggapan tersebut kemudian mendorong orang asing untuk malas belajar bahasa lokal baik bahasa Bali maupun bahasa Indonesia yang menjadi bahasa pengantar komunikasi sehari-hari orang Bali. Jika ini dibiarkan, maka akan muncul kesenjangan yang makin lebar dan jarak antara orang Bali dan orang asing.

Seiring perkembangan zaman, baik ilmu pengetahuan maupun teknologi, kebutuhan orang Bali di era modern saat ini sudah sangat berbeda dengan apa yang dibutuhkan orang Bali sepuluh tahun yang lalu. Dulu, orang Bali tidak menganggap teknologi sebagai sesuatu yang mutlak. Ketika komputer diperkenalkan tahun 1970-an di Amerika Serikat, hampir tidak ada orang Bali yang tertarik untuk membelinya. Namun saat ini, segalanya berubah. Satu hari sejak seri I-Phone 6 diluncurkan misalnya, sebanyak 50 orang Bali membeli produk Apple dari Amerika Serikat ini, di hari pertama. Hal yang sebelumnya merupakan keinginan orang Bali sekarag sudah menjadi kebutuhan. Keinginan itu seperti sepeda motor, mobil, mesin cuci, hingga pakaian renang. Semenjak banyak orang asing bermukim di Bali, tidak sedikit juga orang Bali yang mengikuti kebutuhan-kebutuhan orang asing. Alhasil, gaya belanja yang mereka miliki pun mirip seperti orang asing.

Saat ini produk impor yang masuk ke Indonesia sekaligus ke Bali meliputi beragam jenis barang. Produk impor yang utama adalah barangbarang mewah. Beberapa jenis kendaraan mewah seperti Ferrari, Porsche, 
Ducati, hingga Harley Davidson dijual di Bali. Outlet-outlet kendaraan mewah menjadi hal yang lazim ditemukan saat ini di Bali. Tidak hanya kendaraan, barang-barang mewah impor yang masuk ke Bali lainnya adalah barang-barang elektronik. Cerita unik akan selalu muncul ketika gadget terbaru diluncurkan di Bali, di mana akan terjadi kerumunan masyarakat membanjiri toko-toko elektronik untuk membeli barang dagangan terbaru.

Produk impor yang membanjiri Bali tidak hanya meliputi benda-benda yang memang dibutuhkan orang Bali. Beberapa benda yang merugikan orang asing juga ikut beredar di Bali. Salah satu jenis produk impor yang sangat merugikan adalah narkoba. Tidak bisa dipungkiri, sebagai magnet bagi industri pariwisata internasional, di mana berkumpul jutaan umat manusia dari ratusan bangsa, maka budaya satu sama lain pun berbaur menjadi satu. Turis-turis yang berasal dari beberapa negara yang melegalkan narkoba jenis tertentu seperti Belanda dan Amerika Serikat juga ikut berkumpul di Bali, dan mencoba menjalankan budaya menghisap narkobanya di pulau dewata. Seperti tidak mengindahkan sanksi terberat yang mereka bisa terima, mereka tetap melakukan aktivitas haram tersebut di Bali.

Pengalaman studi selama di Eropa mengajarkan Made Handijaya banyak hal, utamanya betapa orang-orang Eropa sangat memuja kebudayaannya sendiri. Hal sederhananya tercermin dari banyaknya restoran-restoran makanan lokal yang didirikan, dalam berbagai level. Sebenarnya, restoran cepat saji berskala internasional juga ikut berkompetisi dalam bisnis, tapi entah kenapa masyarakat Eropa lebih memilih untuk menikmati hidangan di restoran makanan lokal, daripada restoran asing. Baru saya sadar, ternyata selain karena kecintaan masyarakat Eropa akan budaya asli mereka, tangan pemerintah juga turut bermain di sana. Hal ini banyak dikupas dalam bab "Posisi Tawar Si Bali", khususnya dalam Subbab "Orang Bali Terhanyut Kesenian dan Kebudayaan Orang Asing”.

Untuk menyelamatkan produk asli Bali tentunya dibutuhkan sinergi antara pemerintah, pengusaha produk asli Bali, dan pemangku kepentingan lainnya. Strategi pertama yang bisa dilakukan pemerintah Bali misalnya dengan meniru strategi pemerintah Perancis yaitu dengan memberikan subsidi bagi pebisnis lokal. Pebisnis lokal bisa disubsidi misalnya dengan kredit berbunga rendah, kemudahan pemasaran, penyelenggaraan pameran internasional, dan proteksi dari produk-produk imitasi luar negeri.

Pembangunan dan industri pariwisata di Bali tidak akan berlangsung secara berkelanjutan apabila usaha hanya dilakukan oleh orang Bali saja. Kebersihan di Bali tidak akan terjaga kalau orang asing ikut-ikutan membuang sampah sembarangan seperti orang lokal. Air bersih di Bali akan terus berkurang kalau orang asing melakukan pemborosan air untuk kolam renang mereka. Peran aktif orang asing di Bali sangat diperlukan mengingat kesadaran orang Bali secara rata-rata memang masih rendah. Lagipula 
jika memang benar orang asing datang ke Bali karena mencintai Bali, maka mereka tidak akan keberatan untuk menjaga Bali.

Kemajuan bisnis pariwisata di Bali memberikan harapan pada kemajuan masyarakat Bali, dalam berbagai aspek seperti ekonomi, pendidikan, sosial, dan budaya. Sayangnya, kenyataan di lapangan menunjukkan hal yang berbeda. Dalam beberapa tahun terakhir, terdapat banyak permasalahan maupun ironi yang terjadi antara orang Bali dan orang asing. Banyak orang Bali yang bekerja dengan orang asing, menjual tanahnya pada orang asing, dan mengkomersilkan budayanya sesuai keinginan orang asing. Otokritik Made Handijaya ini mengingatkan kita pada satu cerpen satire berjurul "Karma Tanah" (Kompas, 14 November 2014) yang mengisahkan nasib tragis orang Bali yang menjadi buruh di villa yang dibangun oleh bule di tanah yang dulu miliknya.

Lewat buku ini, penulisnya seperti hendak menyadarkan kita semua bahwa masyarakat Bali saat ini masih belum sepenuhnya sadar, bahwa mereka saat ini sudah seperti tidak berada di kampung halamannya. Buku ini baik dibaca karena otokritiknya bisa menjadi bahan renungan tentang Bali. Mungkin tidak ada istilah terlambat untuk mengawal perkembangan Bali ke arah yang lebih mensejahterakan rakyatnya.

I Nyoman Darma Putra adalah dosen Fakulas Sastra dan Budaya Universitas Udayana, sejak 1 Maret 2014 menjadi Ketua Prodi Magister Kajian Pariwisata, Pascasarjana Universitas Udayana. 